\title{
Tadej Fink \\ FILM NA ZAVODU ZA IZOBRAŽEVANJE IN KULTURO ČRNOMELJ
}

Zavod za izobraževanje in kulturo (ZIK) Črnomelj je javni zavod, ki ga je ustanovila Občina Črnomelj, njegov namen pa je pospeševanje razvoja izobraževanja odraslih, kinematografske in kulturniške dejavnosti. ZIK Črnomelj sestavljata enoti Ljudska univerza in Kulturni dom. Ukvarja se z razvojem novih izobraževalnih programov, svetovanjem odraslim, organiziranjem kulturnih dogodkov in razvojem raznovrstne kulturniške ustvarjalnosti. Že pred desetletji je na ZIK nastal slogan »Izobraževanje in kultura z roko v roki«, ki je naše vodilo pri snovanju novih programov in delu zavoda. Film ima pri tem eno od glavnih vlog. Kino Črnomelj, ki deluje v sklopu ZIK, je namreč osrednji kinematograf v Beli krajini. Prve kinopredstave v Črnomlju so bile v tridesetih leta 20. stoletja, ko so se predvajali nemi filmi ob spremljavi žive glasbe. Med drugo svetovno vojno je bil naš kino edini delujoč kinematograf na osvobojenem ozemlju.

Danes je črnomaljski kino član Art kino mreže Slovenije, ki promovira kakovostne in umetniške filme evropske in svetovne kinematografije. Je tudi član mednarodne mreže Europa Cinemas, v katero se povezujejo kinematografi v Evropi, ki predvajajo kakovosten filmski program. Od leta 2014 je ZIK Črnomelj tudi aktiven partner v projektu Filmskovzgojni program v Art kino mreži Slovenije, ki je namenjen otrokom in mladini. Obsega oglede filmskih projekcij, pogovore po ogledu filma, knjižice za otroke in mlade ter pedagoška gradiva za strokovne delavce. V preteklih dveh šolskih letih smo na območju Bele krajine $\mathrm{v}$ sodelovanju $\mathrm{z}$ različnimi vrtci in šolami pripravili več filmskih projekcij $\mathrm{z}$ vodenimi pogovori. ZIK Črnomelj ponuja tudi izbrane, tematsko naravnane filmske abonmaje, namenjene različnim generacijam s poudarkom na ranljivih ciljnih skupinah starejši odrasli, priseljenci, Romi. V posameznem abonmaju so zbrani kakovostni filmi domače, evropske in svetovne produkcije. Na temelju bogate tradicije in ob zavedanju pomena filmske vzgoje za vse generacije smo na ZIK razvili več lastnih filmskih projektov in programov, ki jih opisujem v nadaljevanju.

\section{SLOVENSKI FILM KOT OGLEDALO ČASA}

Osnovni namen projekta, ki ga izvajamo od leta 2002, je predstavljanje zgodovine sedme umetnosti na Slovenskem. V projektu predstavljamo filmske uspešnice, ki so zaznamovale 
določeno družbeno obdobje. Projekciji starih slovenskih filmskih klasik sledi pogovor s še živečimi igralci in ustvarjalci filmov, v katerem aktivno sodelujejo obiskovalci. V vseh letih projekta smo med drugim predvajali in gostili ustvarjalce filmov: Cvetje v jeseni, Ne joči, Peter, Na svoji zemlji, Kekec, Ples v dežju, To so gadi, Sreča na vrvici, Vesna, Družinski dnevnik, Ne čakaj na maj, Nočni izlet, Grajski biki, Veselica, Veseli veter, Pomlad v Beli krajini, Tistega lepega dne. Pomembnost projekta v slovenskem filmskem prostoru je spoznal Slovenski filmski center, javna agencija, ki ga poleg Občine Črnomelj tudi sofinancira.

\section{FILMSKI TABOR KOLPA}

Projekt, ki smo ga razvili na pobudo belokranjske režiserke Maje Weiss, izvajamo od leta 2008. Spodbuja filmsko ustvarjalnost mladih in jih vzgaja na filmskem področju. Osnovni koncept tabora je ustvarjalno druženje dijakov s slovenskimi filmskimi strokovnjaki ter pridobivanje kakovostnih teoretičnih znanj in praktičnih filmskih izkušenj. Udeleženci tabora, ki prihajajo z vseh koncev Slovenije, so izbrani na podlagi predhodnih filmskih referenc, pomembno merilo pri izboru je tudi opis, zakaj si posameznik želi sodelovati na taboru. Mladi filmarji lahko izbirajo med tremi filmskimi delavnicami: animirani, igrani in dokumentarni film. V treh dneh, kolikor traja tabor, udeleženci preidejo skozi vse faze filmskega ustvarjanja: od ideje, pisanja scenarija, preizkušanja v različnih filmskih vlogah (režija, snemanje, filmska igra, tehnična podpora) do montaže in finalizacije filma. Temo ustvarjanja na Filmskem taboru Kolpa določimo glede na aktualno problematiko in dogajanje v naši družbi. Tako so mladi v preteklosti snemali o schengenski meji (Filmski tabor Kolpa 2012) (Dokumentarni film ..., b. d.), začetkih slovenskega narodnega gledališča v Črnomlju (Filmski tabor Kolpa 2013) (Začetki slovenskega ..., b. d.), etičnosti glede objavljanja na spletu (Filmski tabor Kolpa 2014) (Šeraj in vladaj, 2014), uspešnih mladih belokranjskih podjetnikih (Filmski tabor Kolpa 2016) (Uspešne zgodbe ..., 2016) in podobno. Tudi ta projekt sofinancirata Slovenski filmski center in Občina Črnomelj.

\section{SVETILNIKI IN POSTAJE NA POTI DO ITAKE (Lighthouses and Stations. Trip to Ithaca - LASTTI)}

Projekt se je izvajal v obdobju 2014-2016 v okviru programa Erasmus+. Šlo je za partnersko sodelovanje organizacij za izobraževanje odraslih iz petih evropskih držav: Grčije, Hrvaške, Portugalske, Slovenije in Španije. Kot zanimivost naj omenim, da so koordinatorji projekta iz Španije ZIK Črnomelj kot partnerja v projektu izbrali na priporočilo Veleposlaništva Republike Slovenije v Madridu. Glavni cilj projekta LASTTI je bil s pomočjo filma in filmske kulture uresničiti prizadevanja, da bi izobraževanje odraslih postalo privlačnejše, povečati kakovost izobraževanja, razviti nove pristope, ki bi preprečevali osip in socialno izključenost ranljivih ciljnih skupin. Osnovni poudarek je bil na temi migracij in zaposlovanja. V projektu je vsaka od partnerskih organizacij posnela dokumentarni film, povezan s posebnostmi migracij v svoji državi. Na ZIK je v okviru projekta nastal dokumentarni film o belokranjskih priseljencih z naslovom Doma v Beli 
krajini (Lighthouses and Stations. Trip to Ithaca, 2016). Kot dodana vrednost projekta je v povezavi s Filmskim taborom Kolpa 2015 nastal kratki igrani film o odnosu do tujcev in sprejemanju tujcev z naslovom Zemljokrast (2015). Pomemben poudarek projekta je bil namenjen spoznavanju in boljšemu razumevanju različnosti kultur sodelujočih držav, kar lahko najbolj učinkovito prikažemo skozi gastronomijo in otroške igre. Tako smo posneli postopek priprave in peke belokranjske pogače (Belokranjska pogača, 2015) in staro pastirsko igro koza piš (2015). V okviru dvostranskega srečanja smo s hrvaškimi partnerji posneli tudi hrvaško otroško igro stare košare (2015). Kakovosten prispevek k širitvi gradiva na področju filmske kulture je tudi pedagoški vodnik Pedagogical guide Cinema and Migration »Lighthouses and Stations. Trip to Ithaca« (2016), namenjen izobraževalcem in udeležencem izobraževanja odraslih, v katerem je ponujena evropska dimenzija tehničnega in umetniškega filmskega ustvarjanja. Uporaben je za vse izobraževalne organizacije tudi na mednarodni ravni.

\section{LITERATURA}

Belokranjska pogača [Video]. (2015). Pridobljeno s https://www.youtube.com/watch?v=Q3roADWay8o. Dokumentarni film - Schengenska meja? [Video]. (b. d.). Filmski tabor Kolpa 2012. Pridobljeno s http:// www.filmskitaborkolpa.si/ftk-filmi-2012.html.

Furlan, S., Kavčič, B., Nedič, L. in Vrdlovec, Z. (1994). Filmografija slovenskih celovečernih filmov 1931-1993. Ljubljana: Slovenski gledališki in filmski muzej.

Jurančič, Ž. (2015). Katalog izbranih filmov in spremljevalnih dejavnosti za vzgojno-izobraževalne zavode. Filmskovzgojni program v Art kino mreži Slovenije, šolsko leto 2015/2016. Slovenj Gradec: Art kino mreža Slovenije.

Jurančič, Ž. (2015). Končno poročilo s priporočili za razvoj nacionalnega programa filmske vzgoje $v$ prihodnje. Nacionalni filmskovzgojni program v Art kino mreži Slovenije. Slovenj Gradec: Art kino mreža Slovenije.

Katalog izobraževalne in kulturne ponudbe ZIK 2011/2012. (2011). Črnomelj: ZIK Črnomelj.

Katalog izobraževalne in kulturne ponudbe ZIK 2015/2016. (2015). Črnomelj: ZIK Črnomelj.

Koza piš [Video]. (2015). Pridobljeno s https://www.youtube.com/watch?v=8Kf0NFOGccE.

Lighthouses and Stations. Trip to Ithaca. (2016). Pridobljeno s http://users.sch.gr/Vigklas/erasmusplus/ documentaries.html.

Pedagogical guide Cinema and Migration »Lighthouses and Stations. Trip to Ithaca«. (2016). Pridobljeno s https://drive.google.com/file/d/0BxelMXH8FG19MXZSbzZ1NXNsaWM/view.

Stare košare [Video]. (2015). Pridobljeno s https://www.youtube.com/watch?v=jcpviHIDU-o.

Šraj in vladaj [Video]. (2014). Filmski tabor Kolpa 2014. Pridobljeno s https://www.youtube.com/ watch? $=6 \mathrm{UjDuypDx} 4 \mathrm{~A}$.

Uspešne zgodbe mladih belokranjskih podjetnikov [Video]. (2016). Filmski tabor Kolpa 2016. Pridobljeno s https://www.youtube.com/watch?v=t1JIImzLJJo.

Vrdlovec, Z. (2013). Zgodovina filma na Slovenskem 1896-2011. Ljubljana: UMco

Začetki slovenskega narodnega gledališča v Črnomlju [Video]. (b.d.). Filmski tabor Kolpa 2013. Pridobljeno s http://www.filmskitaborkolpa.si/videoteka/25-filmi-2013.html.

Zavod za izobraževanje in kulturo Črnomelj. (2016). Pridobljeno s http://www.zik-crnomelj.eu/.

Zemljokrast [Video]. (2015). Filmski tabor Kolpa 2015. Pridobljeno s https://www.youtube.com/ watch?v=8XOYPtiOqw0. 